\title{
Influence of Fishery Cooperative Support on Safety Factor Input Behavior of Aquaculturists: The Intermediary Role of Order Fishery and Product Certification
}

\author{
Panfeng Chai ${ }^{1, *}$ and Qiuguang $\mathrm{Hu}^{1,2,3}$ \\ 1 Business School, Ningbo University, 818 Fenghua Road, Jiangbei District, Ningbo 315211, China; \\ huqiuguang@nbu.edu.cn \\ 2 Port Economy Collaborative Innovation Center, Ningbo University, 818 Fenghua Road, Jiangbei District, \\ Ningbo 315211, China \\ 3 Donghai Institute, Ningbo University, 818 Fenghua Road, Jiangbei District, Ningbo 315211, China \\ * Correspondence: chaipanfeng@sina.com.cn; Tel.: +86-1396-826-5110
}

Citation: Chai, P.; Hu, Q. Influence of Fishery Cooperative Support on Safety Factor Input Behavior of Aquaculturists: The Intermediary Role of Order Fishery and Product Certification. Sustainability 2021, 13 , 10714. https://doi.org/10.3390/ su131910714

Academic Editor: Mario D'Amico

Received: 3 August 2021

Accepted: 24 September 2021

Published: 27 September 2021

Publisher's Note: MDPI stays neutral with regard to jurisdictional claims in published maps and institutional affiliations.

Copyright: (c) 2021 by the authors. Licensee MDPI, Basel, Switzerland. This article is an open access article distributed under the terms and conditions of the Creative Commons Attribution (CC BY) license (https:// creativecommons.org/licenses/by/ $4.0 /)$.

\begin{abstract}
This paper used 586 survey data of aquaculturists in the Shandong and Zhejiang provinces of China and built two intermediary effect models by incorporating fishery cooperative support, order fisheries participation, product quality certification, and safety factor input behavior into the same theoretical analysis framework in order to verify the direct influence of fishery cooperative support on safety factor input behavior of aquaculturists, as well as the intermediary effect of order fisheries participation and product quality certification in the relationship between fishery cooperative support and safety factor input behavior of aquaculturists. The research concluded that fishery cooperative support has a significant positive influence on safety factor input behavior. Participation in order fisheries and product quality certification have a partial intermediary effect in the relationship between fishery cooperative support and safety factor input behavior of aquaculturists; their intermediary effect accounts for $10.3 \%$ and $33.7 \%$ of the total effect. The research conclusions can provide reference and suggestions for China's fisheries to better carry out green aquaculture.
\end{abstract}

Keywords: fishery cooperative support; order fisheries participation; product quality certification; safety factor input behavior

\section{Introduction}

In recent years, China's annual aquaculture output had remained at a relatively stable level. It was the only major fishery country in the world where the total amount of aquaculture aquatic products exceeded the total amount of fishing [1]. With the improvement of Chinese residents' living standards and the continuous optimization of consumption demand structure, the total output value of aquaculture industry showed a stable growth trend [2]. In 2019, the total output value of China's aquaculture industry was CNY 939.163 billion. Within the industry, the total output value of mariculture was CNY 354.203 billion, and the aquaculture area was 2.0137 million hectares. The total output value of freshwater aquaculture was CNY 584.96 billion, and the aquaculture area was 5.1167 million hectares. However, aquaculture products quality and safety incidents such as "excessive use of fishery drugs", "excessive feed additives", "hormone residue", and "antibiotic abuse" in China occurred frequently, which had aroused the great concern of the whole society and the widespread concern of consumers [3-5]. The quality and safety of aquaculture products was an important problem to be solved in the process of China's fishery from increasing production to improving quality [6], and most of this problem came from the use of illegal inputs and the abuse of legal inputs in the production of aquaculture products [7]. In 2021, the opinions of the Central Committee of the Communist Party of China and the State Council on comprehensively promoting rural revitalization and 
accelerating agricultural and rural modernization issued by China once again pointed out the need to comprehensively promote green and healthy aquaculture, which fully showed that green aquaculture had attracted the great attention of the Chinese government [8]. The international experience of aquaculture products quality and safety management showed that the wide implementation of whole process of quality management was an important guarantee to improve the quality and safety level of aquatic products [9]. Throughout the quality and safety problems of aquatic products in China, the most frequent occurrence was the input of safety factors in aquaculture. In order to improve the sustainable development ability of fishery, the source control of aquaculture inputs had become an inevitable choice [10].

Since the beginning of China's 40 years of economic reform and opening-up, with the gradual advancement of the development of fishery industrialization, the degree of organization of fishery production and operation in China has been continuously improved, and diversified production and operation organization modes have emerged [11], such as the traditional mode of "fishers + farmers' market + consumers", the wholesale market mode of "fishers + wholesale market + farmers' market + consumers", the order fisheries mode of "fishery cooperatives + aquatic products leading enterprises + dealers + consumers", and the internet plus mode of "internet plus production base or fishery cooperatives + fresh electricity suppliers + consumers". However, "cooperatives + fishermen" had become an important organizational form of aquatic product production and an important carrier to guide aquaculturists to realize the connection between small farmers and the big market. The influence of fishery cooperatives on the green production behavior of aquatic products had been widely a concern of the academic community. Martinez et al. (2011) believed that fishery cooperatives realized the quality and safety of aquatic products through the quality assurance of all links of its industry chain and that the key point was to control the quantity and quality of production factors [12]. Hu et al. (2017) believed that as the vehicle of green production of aquatic products, fishery cooperatives could provide services, help, and support for aquaculturists, which encouraged them to carry out green production [13]. Zhao et al. (2019) believed that fishery cooperatives played a key role in optimizing resource allocation, improving the decentralized operation of small-scale aquaculture farmers and promoting the quality and safety of aquatic products [14]. Liu et al. (2019) believed that fishery cooperatives were a realistic path to solve the lack of self-endowment and external incentive of aquaculturists' safety factor investment behavior [15]. However, there was a lack of research on the safety factor investment behavior of aquaculturists from the perspective of fishery cooperatives, especially on the impact of their cooperative support on the safety factor investment behavior.

During the input of safety factors, order fishery participation and product quality certification were the bridge between aquaculturists and fishery cooperatives and also were a powerful certificate and guarantee for fishery cooperatives to guide aquaculturists' green production. Lu et al. (2005) considered that order fishery was a new model after the internationalization of China's fishery, which promoted the organization, scale, and specialization of fishers, which was mainly aimed at the aquaculture industry [16]. Han et al. (2018) considered that the participation of aquaculturists in an order fishery could not only solve the technical, informational, and agricultural supply constraints faced by small-scale production, but also made specific provisions on the production behavior and product quality of trading products in the form of a beforehand contract, which would guide the safety input behavior of aquaculturists in the production process [17]. Xue et al. (2018) considered that product quality certification was a government-led public brand of safe and high-quality aquatic products [18]. China has recognized that there were mainly pollution-free aquatic products, green aquatic products, and organic aquatic products. These "three products" played an important leading and exemplary role in ensuring the quality and safety of aquatic products. Olaf et al. (2018) believed that the main purpose of implementing certified production of aquatic products was to realize the transformation of their quality and safety from terminal management to source control by strictly controlling 
the input of aquaculture factors [19]. However, there was no systematic research in the existing literature on the influence of cooperative organizations on aquaculturists' behavior of green production through order production and product certification. It only focused on the influence of aquaculturists' participation in cooperatives on product quality and safety and did not promote the change of their production behavior from the perspective of cooperative support.

To sum up, the direct influence of the fishery cooperatives' support of the safety factor investment behavior of aquaculturists also changes the tendency of aquaculturists' safety production through order fishery participation and product quality certification. Based on this, the current article used 586 survey data of aquaculturists in the Shandong and Zhejiang provinces of China, integrated fishery cooperative support, order fishery participation, product quality certification, and aquaculturists' safety factor input behavior into an intermediary effect model and tested the direct influence of fishery cooperation support, as well as the intermediary role of order fishery participation and product quality certification.

\section{Hypotheses and Model}

2.1. Research Hypotheses

\subsubsection{Hypothesis 1}

The support of fishery cooperation organizations reflects the overall performance of an organization's concern or attention to its members [20-22]. When aquaculturists feel supported by fishery cooperatives, they will voluntarily show more attitudes and behaviors that are conducive to the cooperative organization and will improve the quality level of the aquatic products industry chain through the input of safety factors at the source of aquatic product farming. Organizational support consists of emotional support and instrumental support [23,24]. Emotional support means that fishery cooperatives are willing to take the initiative to meet the social and emotional needs of aquaculturists and to encourage them to take actions conducive to achieving the goal of green farming [25]. Instrumental support refers to the support provided by fishery cooperatives for the production process of aquaculturists, such as agricultural materials supply, technical training, information services and production, and marketing guidance, so as to encourage them to voluntarily carry out the production activities of aquatic products in accordance with the organization's specifications $[26,27]$. Based on this, the article proposes Hypothesis 1:

Hypothesis 1 (H1.) The support of fishery cooperatives has a significant positive impact on aquaculturists' behavior of safety factors input.

\subsubsection{Hypothesis 2}

Order contracts can restrict the integrity behavior of various economic entities in the aquatic product market, unify and standardize production, and greatly reduce the transaction costs and supervision costs of intermediaries [28]. In addition, the contracts help increase the availability of agricultural materials, information, technology, and funds for aquaculturists in the process of order fishery participation, reducing uncertainty of the risk and quality effectively in the production process [29]. Additionally, it can reduce the costs of market searching and transaction, which are caused by asymmetry of external information. Therefore, it will ultimately improve aquaculturists' technical ability and willingness to participate in the production of quality and safe aquatic products, cause them to reduce the use of fishery drugs, and standardize production in strict accordance with the requirements of the organization. Based on this, the article proposes Hypothesis 2:

Hypothesis 2 (H2.) Order fisheries participation has an intermediary effect in the relationship between the fishery cooperatives' support and the aquaculturists' behavior of safety factors input. 


\subsubsection{Hypothesis 3}

Fishery cooperatives that promote product quality certification not only can cooperate with aquaculturists in the production process of aquatic products industry chain by establishing a benefit connection mechanism of "risk sharing and benefit sharing" with them, but also can affect their availability of aquaculture materials, information, technology, and other factors [30]. It can reduce the operation standard difficulty of many aquaculturists under the requirements of product quality certification, promote the adoption and improvement of green technology by them, and enhance the production capacity of quality and safe aquatic products [31]. On the other hand, cooperative support can enhance the awareness and willingness of aquaculturists to "three products and one standard" product certification, and then radiate and drive them to carry out quality and safety production [32]. Based on this, the article proposes Hypothesis 3:

Hypothesis 3 (H3.) Product quality certification has an intermediary effect in the relationship between the fishery cooperatives' support and the aquaculturists' behavior of safety factors input.

\subsection{Theoretical Model}

Based on the above analysis, the authors constructed a theoretical model of the relationship between fishing cooperatives' support, participation in order fisheries, product quality certification, and safety factors input behavior of aquaculturists, as shown in Figure 1.

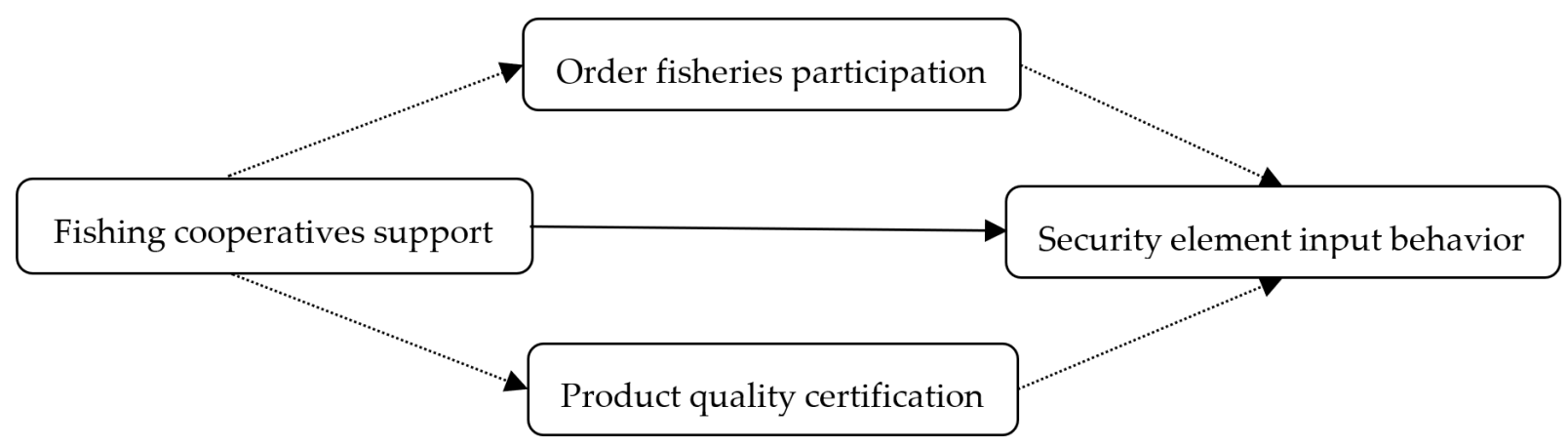

Figure 1. Theoretical model.

\section{Materials and Methods}

\subsection{Description of Research Variables}

\subsubsection{Dependent Variable}

Due to the particular nature of aquaculture, the quality and safety problems of aquaculture mainly focus on seedling, drug, and pollutant residues. The dependent variable studied in this paper was the safety factor input behavior of aquaculturists, which is mainly defined from the three perspectives of seed, feed, and fishery medicine. The measurement standard of seedlings mainly the health and quality of seedlings [33], the measurement standard of feed is mainly the use of additives and the basis for the use of additives [34,35], and the measurement standard of fishery drugs is mainly the key factors of purchasing fishery drugs, the basis for judging the effect of fishery drugs, the application amount of fishery drugs, and the impact of fishery drugs on aquaculture water quality and environment [36-38]. Only when the above three elements are in line with quality and safety, is it considered that the safety factor input behavior of aquaculturists is safe.

\subsubsection{Key Independent Variable}

The key independent variable studied in this paper is fishing cooperatives' support. Referring to the research results of Ling Wenquan and others on the measurement indicators of organizational support [23], the support of fishery cooperatives was divided into 
two dimensions: emotional support and instrumental support. Emotional support was measured by four indicators: respect, attention, trust, and care of fishery cooperatives for aquaculturists, and instrumental support was measured by four indicators: agricultural materials supply, technical training, information service, and production and marketing guidance provided to aquaculturists by fishery cooperatives. According to Likert's five component scale method, the eight categories were assigned as $1-5$ from low to high, which is shown in Table 1.

Table 1. Variable description of fishing cooperatives' support.

\begin{tabular}{|c|c|c|c|c|c|c|}
\hline \multirow{2}{*}{ Dimension } & \multirow{2}{*}{ Index } & \multirow{2}{*}{ Meaning and Measurement } & \multirow{2}{*}{ Mean } & \multirow{2}{*}{$\begin{array}{l}\text { Standard } \\
\text { Deviation }\end{array}$} & \multicolumn{2}{|c|}{ Factor Analysis Results } \\
\hline & & & & & Factor 1 & Factor 2 \\
\hline \multirow{4}{*}{$\begin{array}{l}\text { Emotional } \\
\text { support }\end{array}$} & $\begin{array}{l}\text { The fishery cooperative } \\
\text { society you participate in } \\
\text { respects your } \\
\text { production decisions. }\end{array}$ & $\begin{array}{l}1=\text { very disrespect; } \\
2=\text { disrespect; } \\
3=\text { fair } ; 4 \text { = respect; } \\
5=\text { very respect }\end{array}$ & 3.690 & 1.160 & 0.806 & 0.207 \\
\hline & $\begin{array}{l}\text { The fishery cooperative } \\
\text { society you participate in } \\
\text { values your } \\
\text { personal interests. }\end{array}$ & $\begin{array}{l}1=\text { very little attention; } \\
2=\text { not important } 3=\text { fair; } \\
4=\text { important; } \\
5=\text { very important }\end{array}$ & 3.904 & 1.104 & 0.872 & 0.157 \\
\hline & $\begin{array}{l}\text { The fishery cooperative } \\
\text { society you participate in } \\
\text { trusts the quality of } \\
\text { your products. }\end{array}$ & $\begin{array}{l}1=\text { very distrust } \\
2=\text { distrust } 3=\text { fair } \\
4=\text { trust } ; 5=\text { very trust }\end{array}$ & 3.712 & 1.015 & 0.813 & 0.153 \\
\hline & $\begin{array}{l}\text { The fisheries cooperative } \\
\text { you participate in will give } \\
\text { you care when you are } \\
\text { in difficulty. }\end{array}$ & $\begin{array}{l}1=\text { Not very concerned; } \\
2=\text { Not concerned; } \\
3=\text { General } ;=\text { Cared } \\
5=\text { Very concerned }\end{array}$ & 3.550 & 1.110 & 0.811 & 0.081 \\
\hline \multirow{4}{*}{$\begin{array}{l}\text { Instrumental } \\
\text { support }\end{array}$} & $\begin{array}{l}\text { The fishery cooperative } \\
\text { society you participate in } \\
\text { provides } \\
\text { aquaculture information. }\end{array}$ & $\begin{array}{l}1=\text { Never provide } \\
2=\text { Almost not provide } ; \\
3=\text { Provide but not meet } \\
4=\text { Provide conditionally } \\
5=\text { Provide can meet }\end{array}$ & 3.445 & 1.109 & 0.195 & 0.815 \\
\hline & $\begin{array}{l}\text { The fishery cooperative } \\
\text { society you participate } \\
\text { in provides } \\
\text { technical training. }\end{array}$ & $\begin{array}{l}1=\text { Never provide } \\
2=\text { Almost not provide } \\
3=\text { Provide but not meet } \\
4=\text { Provide conditionally } \\
5=\text { Provide can meet }\end{array}$ & 3.480 & 0.998 & 0.184 & 0.797 \\
\hline & $\begin{array}{l}\text { The fishery cooperative } \\
\text { society you participate } \\
\text { in provides } \\
\text { information services. }\end{array}$ & $\begin{array}{l}1=\text { Never provide } \\
2=\text { Almost not provide } \\
3=\text { Provide but not meet } \\
4=\text { Provide conditionally } \\
5=\text { Provide can meet }\end{array}$ & 3.541 & 1.066 & 0.103 & 0.812 \\
\hline & $\begin{array}{l}\text { The fishery cooperative } \\
\text { society you participate in } \\
\text { provides production and } \\
\text { marketing guidance. }\end{array}$ & $\begin{array}{l}1=\text { Never provide } \\
2=\text { Almost not provide } ; \\
3=\text { Provide but not meet } \\
4=\text { Provide conditionally } \\
5=\text { Provide can meet }\end{array}$ & 3.672 & 1.121 & 0.104 & 0.823 \\
\hline
\end{tabular}

The commonality corresponding to the survey sample data was calculated by using SPSS 24.0 software, and its values were higher than 0.4, indicating that the sample information could be effectively extracted. Meanwhile, the KMO test value was 0.831 , which is greater than 0.7, and the approximate chi-square value of Bartlett's sphere test was 814.676 (sig = 0.000), which means that the sample data were valid and suitable for factor analysis. The maximum variance method was used for factor rotation, and the cumulative variance contribution rate was $69.43 \%$. The variance contribution rate of common factor 
1 was $35.27 \%$, including the respect, attention, trust, and care of fishery cooperatives to aquaculturists, which was named emotional support. The variance contribution rate of common factor 2 was $34.16 \%$, including agricultural materials supply, technical training, information service, production and marketing guidance and other variables provided by fishery cooperatives for aquaculture farmers, which was named instrumental support. Combined with the factor load coefficients, the weighted average method was used to calculate the total factor variable score of organizational support. Taking the variance contribution rate of each common factor as the weight, the factor score values of emotional support and instrumental support were weighted and summed to calculate the fishery cooperative support index of each sample. The specific calculation formula was as follows:

Fishing cooperatives' support $=($ emotional support $\times 35.27 \%+$ instrumental support $\times 34.16 \%) / 69.43 \%$

\subsubsection{Intermediary Variables}

The intermediary variables in this study were order fishery participation and product quality certification. The intermediate variables adopted the binary assignment method to measure the order fishery participation and product quality certification of aquaculturists; that is, the order fishery participation was characterized by whether to participate in the order contract of fishery cooperatives, and the product quality certification was verified by whether it had obtained the pollution-free agricultural product standards, green food standards, and organic food standards stipulated by the government.

\subsubsection{Control Variables}

In order to avoid interference from other variables that may have affected the safety factor input behavior of aquaculturists, control variables such as individual characteristics of aquaculturists and their family characteristics were added to the empirical model. The individual characteristic variables included gender, age, and education level of aquaculture farmers. The family characteristic variables included total number of families, number of labor forces, total household income, aquaculture areas, aquaculture years, and sales income of aquatic products. The meanings and descriptive statistics of the main variables used in this study are shown in Table 2.

Table 2. Definition, assignment, and descriptive statistics of variables.

\begin{tabular}{|c|c|c|c|}
\hline Variable Name & Variable Definition and Description & Mean & Standard Deviation \\
\hline \multirow{5}{*}{$\begin{array}{l}\text { Security element input } \\
\text { behavior }\end{array}$} & $\begin{array}{l}\text { Your family's aquatic product seedlings are healthy and } \\
\text { high-quality: } 1=\text { completely disagree; } 2=\text { disagree; } \\
3=\text { basically agree; } 4=\text { agree; } 5=\text { completely agree }\end{array}$ & 3.603 & 1.036 \\
\hline & $\begin{array}{l}\text { In order to ensure the quality and safety of aquatic products, } \\
\text { you generally do not use feed additives in your feed: } \\
1 \text { = completely disagree; } 2 \text { = disagree; } 3=\text { basically agree; } \\
4=\text { agree; } 5=\text { completely agree }\end{array}$ & 3.607 & 1.171 \\
\hline & $\begin{array}{l}\text { If you use feed additives, you will strictly implement the } \\
\text { safety index limit of the fishery compound feed: } \\
1 \text { = completely disagree; } 2 \text { = disagree; } 3=\text { basically agree; } \\
4 \text { = agree; } 5=\text { completely agree }\end{array}$ & 3.734 & 1.352 \\
\hline & $\begin{array}{l}\text { You regard the quality and safety of aquatic products as the } \\
\text { most critical factor when purchasing fishery drugs: } \\
1=\text { completely disagree; } 2=\text { disagree; } 3=\text { basically agree; } \\
4=\text { agree; } 5 \text { = completely agree }\end{array}$ & 3.533 & 1.045 \\
\hline & $\begin{array}{l}\text { You will control the amount of fishery drugs used in strict } \\
\text { accordance with the instructions and determine the effect: } \\
1=\text { completely disagree; } 2=\text { disagree; } 3=\text { basically agree; } \\
4=\text { agree; } 5=\text { completely agree }\end{array}$ & 3.524 & 1.078 \\
\hline
\end{tabular}


Table 2. Cont.

\begin{tabular}{|c|c|c|c|}
\hline Variable Name & Variable Definition and Description & Mean & Standard Deviation \\
\hline & $\begin{array}{l}\text { Do you think the use of safe and low-residue fishery drugs is } \\
\text { very important to the aquaculture water quality environment: } \\
1 \text { = completely disagree; } 2 \text { = disagree; } 3 \text { = basically agree; } \\
4 \text { = agree; } 5 \text { = completely agree }\end{array}$ & 3.437 & 1.005 \\
\hline Fishing cooperatives' support & Emotional support and tool-supported factor analysis results & 3.626 & 0.743 \\
\hline Order fisheries participation & $\begin{array}{l}\text { Have you participated in the fishery cooperative's order } \\
\text { contract: } 0=\text { No; } 1=\text { Yes }\end{array}$ & 0.349 & 0.478 \\
\hline Product quality certification & $\begin{array}{l}\text { Whether your aquatic products have been certified by the } \\
\text { government or fishery cooperatives (certificates of } \\
\text { pollution-free agricultural products, green food, organic food): } \\
0=\text { No; } 1 \text { = Yes }\end{array}$ & 0.590 & 0.493 \\
\hline Gender & Respondent's gender: $0=$ male; $1=$ female & 0.166 & 0.373 \\
\hline Age & The actual age of the respondent (years) & 40.603 & 8.916 \\
\hline Education level & $\begin{array}{l}\text { Respondent's education level: } 1 \text { = primary school and below; } \\
2=\text { junior high school; } \\
3=\text { high school or technical secondary school; } \\
4=\text { junior college; } 5 \text { = undergraduate and above }\end{array}$ & 1.913 & 0.784 \\
\hline Total number of households & Household population of the respondent (person) & 5.559 & 1.783 \\
\hline Number of farming laborers & Number of surveyed households aquaculture (person) & 2.764 & 1.095 \\
\hline Total household income & Annual household income of respondents (ten thousand) & 29.253 & 5.384 \\
\hline Aquaculture area & $\begin{array}{l}\text { The total aquatic product farming area of the surveyed } \\
\text { household (mu) }\end{array}$ & 19.712 & 4.962 \\
\hline Years of aquaculture & $\begin{array}{l}\text { The number of years the respondent has engaged in aquatic } \\
\text { product cultivation (years) }\end{array}$ & 9.498 & 5.176 \\
\hline $\begin{array}{l}\text { Sales revenue of aquatic } \\
\text { products }\end{array}$ & $\begin{array}{l}\text { Respondents' household income from aquatic products sales } \\
\text { (ten thousand) }\end{array}$ & 24.279 & 6.609 \\
\hline
\end{tabular}

\subsection{Source of Sample Data}

The data of this paper mainly came from the questionnaires. The sample objects were aquaculturists in Rongcheng City, Shandong Province, and Xiangshan City, Zhejiang Province of China. According to the economic level, topographic characteristics, and breeding characteristics of the sample areas, representative regional aquaculturists were selected to issue questionnaires through the fishery management department and the university resource platform. In order to ensure the authenticity and scientific nature of the survey, the questionnaires were distributed in the form of stratified level-by-level sampling and random sampling. The specific sampling process was as follows: 5 townships (streets) were randomly selected in each area, 6 villages were randomly selected in each township (street), and finally 10 aquaculture households were randomly selected in each village. In this survey, 300 questionnaires were distributed in Rongcheng City and Xiangshan City, respectively, and a total of 600 questionnaires were distributed in the whole data survey process. After excluding some questionnaires with missing data and inconsistent information, 586 valid questionnaires were obtained, with a questionnaire recovery rate of $97.7 \%$.

\subsection{Empirical Model Selection}

Through the intermediary effect test method, this paper constructed the intermediary effect test model for empirical analysis. The specific regression model is as follows:

$$
S I^{\prime}=\alpha_{0}+\alpha_{1} O S+\alpha_{2} X+\mu_{1}
$$




$$
\begin{gathered}
M=\beta_{0}+\beta_{1} O S+\beta_{2} X+\mu_{2} \\
S I^{\prime \prime}=c_{0}+c_{1} O S+c_{2} M+c_{3} X+\mu_{3}
\end{gathered}
$$

In Formulas (1)-(3), the dependent variable is abbreviated as "SI", the independent variable is abbreviated as "OS", and the intermediary variable is replaced by " $M$ ", which includes order fisheries participation $(\mathrm{OP})$ and product quality certification $(\mathrm{PB})$, while other control variables are represented by " $X$ "; $\mu_{\mathrm{i}}$ is a random disturbance item, and $\alpha_{\mathrm{i}}, \beta_{\mathrm{i}}$, $c_{i}$ are model regression coefficients. The specific testing process of the intermediary effect model is as follows:

The first step was regression analysis. Previous studies showed that when the number of dependent variables categories is large, we should consider using linear regression analysis to test the intermediary effect; when the intermediary variables are binary variables, we should consider using logistic regression for testing. Therefore, the intermediary effect test in this article drew on the method and performed three regressions: (1) performed the linear regression of $O S \rightarrow S I$, and obtain the coefficient $\alpha_{1}$ and its corresponding standard error estimate; (2) performed $O S \rightarrow O P$ and $O S \rightarrow P B$ logistic regression to obtain coefficient $\beta_{1}$ and its corresponding standard error estimate; (3) performed linear regression of $O S$ and $O P \rightarrow S I$ with $O S$ and $P B \rightarrow S I$ to obtain coefficients $c_{1}, c_{2}$, and their corresponding standard error estimates.

The second step was standardization. The regression coefficients from the first step were standardized. We calculated the variance and standard deviation of the dependent variable, independent variable, and intermediate variable, then calculated the standardized logistic regression coefficients $\alpha_{1}{ }^{s t d}, \beta_{1}{ }^{s t d}, c_{1}{ }^{s t d}$, and $c_{2}{ }^{\text {std }}$. The formula is as follows:

$$
\begin{gathered}
S I^{\prime}=\operatorname{LogitP}(S I=1 \mid O S)=\ln \frac{P(S I=1 \mid O S)}{P(S I=0 \mid O S)} \\
S I^{\prime \prime}=\operatorname{LogitP}(S I=1 \mid M, O S)=\ln \frac{P(S I=1 \mid M, O S)}{P(S I=0 \mid M, O S)} \\
S D\left(S I^{\prime}\right)=\sqrt{\alpha_{1}^{2} \operatorname{var}(O S)+\frac{\pi^{2}}{3}}, \\
S D\left(S I^{\prime \prime}\right)=\sqrt{c_{1}^{2} \operatorname{var}(O S)+c_{2}^{2} \operatorname{var}(M)+2 c_{1} c_{2} \operatorname{cov}(O S, M)+\frac{\pi^{2}}{3}}, \\
\alpha_{1}^{s t d}=\alpha_{1} \cdot \frac{S D(O S)}{S D\left(S I^{\prime}\right)}, \beta_{1}^{s t d}=\beta_{1} \cdot \frac{S D(O S)}{S D(M)}, c_{1}^{s t d}=c_{1} \cdot \frac{S D(O S)}{S D\left(S I^{\prime \prime}\right)}, \\
c_{2}^{s t d}=c_{2} \cdot \frac{S D(M)}{S D\left(S I^{\prime \prime}\right)}
\end{gathered}
$$

Among them, $\frac{\pi^{2}}{3}$ is the variance of the standard logistic distribution.

In the third step, the Sobel method was used to test the significance of the $\mathrm{z}$ value. First, we calculated the standard error corresponding to each standardized regression coefficient and then calculated the standard error corresponding to the mediation effect. The specific formula is as follows:

$$
\begin{aligned}
& S E\left(\alpha_{1}^{s t d}\right)=S E\left(\alpha_{1}\right) \cdot \frac{S D(O S)}{S D\left(S I^{\prime}\right)}, S E\left(\beta_{1}^{s t d}\right)=S E\left(\beta_{1}\right) \cdot \frac{S D(O S)}{S D(M)} \\
& S E\left(c_{1}^{s t d}\right)=S E\left(c_{1}\right) \cdot \frac{S D(O S)}{S D\left(S I^{\prime \prime}\right)}, S E\left(c_{2}^{s t d}\right)=S E\left(c_{2}\right) \cdot \frac{S D(M)}{S D\left(S I^{\prime \prime}\right)} \\
& S E\left(\beta_{1} c_{2}^{s t d}\right)=\sqrt{\left(c_{2}^{s t d}\right)^{2}\left(S E\left(\beta_{1}^{s t d}\right)\right)^{2}+\left(\beta_{1}^{s t d}\right)^{2}\left(S E\left(c_{2}^{s t d}\right)\right)^{2}}
\end{aligned}
$$


Finally, the $z$ value was calculated, $Z=\frac{\beta_{1} c_{2}^{s t d}}{S E\left(\beta_{1} c_{2}^{\text {std }}\right)}$. The test result was considered significant if the $z$ value was greater than 1.96 , indicating that there was a mediation effect, and the mediation effect accounted for $\frac{\beta_{1} \cdot c_{2}^{\text {std }}}{\beta_{1} \cdot \mathcal{c}_{2}^{\text {std }}+\alpha_{1}^{s t d}}$.

\section{Results}

In this paper, the combination of linear regression and logistic regression was used to analyze the safety factor input behavior of aquaculturists. The test of the intermediary effect was also divided into two steps to complete. From Tables 3 and 4 , the $\mathrm{R}^{2}$ of each empirical model passed the significance test, which shows that the application of the test model was reasonable.

Table 3. The intermediate effect test and estimation results of order agriculture participation on the safety factor input behavior.

\begin{tabular}{|c|c|c|c|}
\hline \multirow[b]{2}{*}{ Variable } & \multicolumn{3}{|c|}{ Dependent Variable } \\
\hline & $\begin{array}{c}\text { Safe Investment } \\
\text { Behavior } \\
\text { (1) }\end{array}$ & $\begin{array}{l}\text { Order Fisheries } \\
\text { Participation } \\
\text { (2) }\end{array}$ & $\begin{array}{c}\text { Safe Investment } \\
\text { Behavior } \\
\text { (3) }\end{array}$ \\
\hline Fishing cooperatives' support & $\begin{array}{l}0.561 * * * \\
(9.630)\end{array}$ & $\begin{array}{l}1.581 * * * \\
(4.371)\end{array}$ & $\begin{array}{l}0.503^{* * *} \\
(8.475)\end{array}$ \\
\hline Order fisheries participation & & & $\begin{array}{l}0.427^{* * *} \\
(3.432)\end{array}$ \\
\hline Gender & $\begin{array}{c}0.053 \\
(0.455) \\
\end{array}$ & $\begin{array}{c}0.251 \\
(0.399) \\
\end{array}$ & $\begin{array}{c}0.024 \\
(0.212) \\
\end{array}$ \\
\hline Age & $\begin{array}{l}-0.014^{* *} \\
(-2.862)\end{array}$ & $\begin{array}{l}-0.131^{* * *} \\
(-4.161)\end{array}$ & $\begin{array}{l}-0.010 \\
(-1.952)\end{array}$ \\
\hline Education level & $\begin{array}{l}0.125 * \\
(2.264)\end{array}$ & $\begin{array}{l}0.639 * \\
(2.107)\end{array}$ & $\begin{array}{c}0.107 \\
(1.969)\end{array}$ \\
\hline Total number of households & $\begin{array}{c}-0.023 \\
(-0.601)\end{array}$ & $\begin{array}{c}0.205 \\
(1.002)\end{array}$ & $\begin{array}{c}-0.034 \\
(-0.889)\end{array}$ \\
\hline Number of farming laborers & $\begin{array}{c}0.019 \\
(0.308) \\
\end{array}$ & $\begin{array}{c}-0.511 \\
(-1.504)\end{array}$ & $\begin{array}{c}0.036 \\
(0.586) \\
\end{array}$ \\
\hline Total household income & $\begin{array}{c}0.012 \\
(0.957) \\
\end{array}$ & $\begin{array}{c}0.014 \\
(0.247) \\
\end{array}$ & $\begin{array}{c}0.013 \\
(1.013) \\
\end{array}$ \\
\hline Aquaculture area & $\begin{array}{c}-0.021 \\
(-0.817)\end{array}$ & $\begin{array}{l}0.333 * \\
(2.475)\end{array}$ & $\begin{array}{c}-0.033 \\
(-1.311)\end{array}$ \\
\hline Years of aquaculture & $\begin{array}{l}0.050 * * * \\
(3.786)\end{array}$ & $\begin{array}{l}0.146^{*} \\
(2.348)\end{array}$ & $\begin{array}{l}0.041 * * \\
(3.096)\end{array}$ \\
\hline $\begin{array}{l}\text { Sales revenue of aquatic } \\
\text { products }\end{array}$ & $\begin{array}{l}0.037 * \\
(2.391)\end{array}$ & $\begin{array}{c}0.097 \\
(1.333)\end{array}$ & $\begin{array}{l}0.032 * \\
(2.114)\end{array}$ \\
\hline Intercept term & $\begin{array}{c}0.629 \\
(1.472)\end{array}$ & $\begin{array}{l}-13.718 * * * \\
(-5.119)\end{array}$ & $\begin{array}{l}1.002 * \\
(2.323)\end{array}$ \\
\hline $\mathrm{R}^{2}$ & 0.480 & 0.539 & 0.506 \\
\hline F value/likelihood ratio test & $20.083^{* * *}$ & $159.766^{* * *}$ & $20.231^{* * *}$ \\
\hline
\end{tabular}

Note: ${ }^{* * *},{ }^{* *},{ }^{*}$ indicate significance at the statistical level of $1 \%, 5 \%$, and $10 \%$, respectively. The $t$ value is in the brackets. 
Table 4. The intermediate effect test and estimation results of product quality certification on the safety factor input behavior.

\begin{tabular}{|c|c|c|c|}
\hline \multirow[b]{2}{*}{ Variable } & \multicolumn{3}{|c|}{ Dependent Variable } \\
\hline & $\begin{array}{l}\text { Safe Investment } \\
\text { Behavior } \\
\text { (1) }\end{array}$ & $\begin{array}{l}\text { Product Quality } \\
\text { Certification } \\
\text { (2) }\end{array}$ & $\begin{array}{l}\text { Safe Investment } \\
\text { Behavior } \\
\text { (3) }\end{array}$ \\
\hline Fishing cooperatives' support & $\begin{array}{l}0.561^{* * * *} \\
(9.630)\end{array}$ & $\begin{array}{l}2.480 * * * \\
(6.612)\end{array}$ & $\begin{array}{c}0.372 * * * \\
(5.738)\end{array}$ \\
\hline Product quality certification & & & $\begin{array}{l}0.602 * * * \\
(5.457)\end{array}$ \\
\hline Gender & $\begin{array}{c}0.053 \\
(0.455)\end{array}$ & $\begin{array}{l}-0.729 \\
(-1.165)\end{array}$ & $\begin{array}{c}0.113 \\
(1.021)\end{array}$ \\
\hline Age & $\begin{array}{l}-0.014^{* *} \\
(-2.862)\end{array}$ & $\begin{array}{l}-0.061 * \\
(-2.561)\end{array}$ & $\begin{array}{l}-0.010 * \\
(-2.052)\end{array}$ \\
\hline Education level & $\begin{array}{l}0.125^{*} \\
(2.264)\end{array}$ & $\begin{array}{l}0.773^{* *} \\
(2.757)\end{array}$ & $\begin{array}{c}0.077 \\
(1.457)\end{array}$ \\
\hline Total number of households & $\begin{array}{l}-0.023 \\
(-0.601)\end{array}$ & $\begin{array}{l}-0.199 \\
(-1.093)\end{array}$ & $\begin{array}{l}-0.007 \\
(-0.185)\end{array}$ \\
\hline Number of farming laborers & $\begin{array}{c}0.019 \\
(0.308)\end{array}$ & $\begin{array}{c}0.027 \\
(0.091)\end{array}$ & $\begin{array}{c}0.018 \\
(0.310)\end{array}$ \\
\hline Total household income & $\begin{array}{c}0.012 \\
(0.957)\end{array}$ & $\begin{array}{c}0.008 \\
(0.149)\end{array}$ & $\begin{array}{c}0.011 \\
(0.962)\end{array}$ \\
\hline Aquaculture area & $\begin{array}{c}-0.021 \\
(-0.817)\end{array}$ & $\begin{array}{c}0.016 \\
(0.133)\end{array}$ & $\begin{array}{l}-0.025 \\
(-1.042)\end{array}$ \\
\hline Years of aquaculture & $\begin{array}{c}0.050 \text { *** } \\
(3.786)\end{array}$ & $\begin{array}{c}0.051 \\
(0.872)\end{array}$ & $\begin{array}{c}0.048^{* * *} \\
(3.820)\end{array}$ \\
\hline $\begin{array}{l}\text { Sales revenue of aquatic } \\
\text { products }\end{array}$ & $\begin{array}{l}0.037 * \\
(2.391)\end{array}$ & $\begin{array}{l}0.235^{* *} \\
(3.011)\end{array}$ & $\begin{array}{c}0.021 \\
(1.416)\end{array}$ \\
\hline Intercept term & $\begin{array}{c}0.629 \\
(1.472)\end{array}$ & $\begin{array}{c}-12.906^{* * *} \\
(-5.276)\end{array}$ & $\begin{array}{l}1.286 * * \\
(3.065)\end{array}$ \\
\hline $\mathrm{R} 2$ & 0.480 & 0.447 & 0.542 \\
\hline F value/likelihood ratio test & $20.083^{* * *}$ & $138.624 * * *$ & $23.375^{* * *}$ \\
\hline
\end{tabular}

Note: ${ }^{* * *},{ }^{* *},{ }^{*}$ indicate significance at the statistical level of $1 \%, 5 \%$, and $10 \%$, respectively. The $t$ value is in the brackets.

\subsection{The Intermediary Effect Test of Order Fisheries Participation}

The models (1)-(3) in Table 3 are the test results of the intermediary effect of the participation of order fisheries in the relationship between fishing cooperatives' support and safety factor input behavior of aquaculturists. According to the intermediary effect test procedure:

First, we performed the linear regression of the fishing cooperatives' support for the safety factor input behavior. From the model (1) $(O S \rightarrow S I)$, it can be seen that the fishing cooperatives' support had a significant positive impact on the safety factor input behavior of aquaculturists, with a regression coefficient of 0.561 , which shows that the fishing cooperatives' support can effectively improve the safety factor input behavior of aquaculturists. The hypothesis $\mathrm{H} 1$ can be verified.

Secondly, we performed the logistic regression of the fishing cooperatives' support for the order fisheries participation. The test result of model (2) $(O S \rightarrow O P)$ shows that the fishing cooperatives' support had a significant positive impact on aquaculturists' order fishery participation decision-making, and the regression coefficient was 1.581, indicating that the fishing cooperatives' support can significantly increase the probability of farmers participating in order fishery. 
Finally, we performed a linear regression of the influence of the fishing cooperatives' support and order fishery participation on the safety factor input behavior. The model (3) $(O S \rightarrow O P \rightarrow S I)$ shows that after the introduction of order fishery participation, it had a significant positive impact on the safety factor input behavior, and the regression coefficient was 0.427 , indicating that the participation of order fishery will increase the safety factor input behavior. At the same time, the fishing cooperatives' support still had a significant positive impact on the safety factor input behavior, and the regression coefficient was reduced from 0.561 to 0.503 . Combining the linear regression and logistic regression estimation results of models (1)-(3), we adopted the Sobel test and obtained $Z=2.65>1.96$. It indicates that the participation of order fisheries has a part in the relationship between the fishing cooperatives' support and the safety factor input behavior of aquaculturists. The intermediary effect was 0.058 , and the proportion was $10.3 \%$. It indicates that $10.3 \%$ of the effect of the fishing cooperatives' support on the safety factor input behavior of aquaculturists came from the participation of order fisheries. $R^{2}$ increased from 0.480 in model (1) to 0.506 in model (3), indicating that the intermediary variable significantly improves the model's interpretation of the safety factor input behavior of aquaculturists. The hypothesis $\mathrm{H} 2$ can be verified.

\subsection{The Intermediary Effect Test of Product Quality Certification}

The models (1)-(3) in Table 4 are the test results of the intermediary effect of product quality certification in the relationship between fishing cooperatives' support and safety factor input behavior of aquaculturists. According to the intermediary effect test procedure:

First, we performed the linear regression of the fishing cooperatives' support for the safety factor input behavior. From the model (1) $(O S \rightarrow S I)$, it can be seen that the fishing cooperatives' support had a significant positive impact on the safety factor input behavior, with a regression coefficient of 0.561 , which shows that the fishing cooperatives' support can improve the safety factor input behavior of aquaculturists effectively.

Secondly, we performed the logistic regression of the fishing cooperatives' support for the product quality certification. From the model (2) $(O S \rightarrow P B)$, it shows that the fishing cooperatives' support had a significant positive impact on the product quality certification, with a regression coefficient of 2.480, indicating that the fishing cooperatives' support can significantly improve the possibility of product quality certification.

Finally, we performed a linear regression of the influence of the fishing cooperatives support and product quality certification on the safety factor input behavior. The model (3) $(O S \rightarrow P B \rightarrow S I)$ shows that after the introduction of product quality certification, it had a significant positive impact on the safety factor input behavior, with a regression coefficient of 0.602 , indicating that product quality certification will encourage aquaculturists to enhance the safety factors input behavior. At the same time, the fishing cooperatives support still had a significant positive impact on the safety factor input behavior, and the regression coefficient was reduced from 0.561 to 0.372 . Combining the linear regression and logistic regression estimation results of models (1)-(3), we adopted the Sobel test and obtained $Z=5.57>1.96$. It indicates that product quality certification has a part in the relationship between the fishing cooperatives' support and the safety factor input behavior of aquaculturists. The intermediary effect was 0.189 , and the proportion was $33.7 \%$. It indicates that $33.7 \%$ of the effect of the fishing cooperatives' support on the safety factor input behavior came from product quality certification. R2 increased from 0.480 in model (1) to 0.542 in model (3), indicating that the intermediary variable significantly improves the model's interpretation of the safety factor input behavior of aquaculturists. The hypothesis $\mathrm{H} 3$ was verified.

\section{Discussion}

5.1. Influence of Fishery Cooperative Support on Safety Factor Input Behavior of Aquaculturists

The empirical results indicate that the fishery cooperatives' support has a significant positive influence on the safety factor input behavior of aquaculturists. The possible 
explanation is that the emotional support of fishery cooperatives helps to meet the social and psychological needs of aquaculturists, further stimulates the potential of their mutual benefit psychology, and encourages them to make positive return behavior effectively, so as to enhance their willingness to invest in safety factors [39]. Additionally, the instrumental support of fishery cooperatives can provide information, capital, technology, and training to aquaculturists for enhancing their ability to broaden sales channels, improve technical level, alleviate capital pressure, reduce transaction costs, and resist risks [40]. Based on reciprocal behavior theory and social exchange theory, when aquaculturists perceive the stronger support from fishery cooperatives, the more active they will be in the process of aquatic product production. It reflects the influence of fishery cooperatives' support on the maintenance of the psychological contract and the change in behavior norms of aquaculturists.

\subsection{Intermediary Effect Analysis of Order Fishery Participation}

The empirical results indicate that order fishery participation has partial intermediary effects in the relationship between the fishery cooperatives' support and the safety factor input behavior of aquaculturists, and the intermediary effects account for $10.3 \%$ of the total effects, which indicates that partial effects of fishery cooperative support on the safety factor input behavior come from order fishery participation. The possible explanation is that the fishery cooperatives' support helps to improve the availability of agricultural materials, information, technology, and financial services for aquaculturists in the process of order fishery participation [41], effectively reduces the risk and quality uncertainty in the production process, improves their psychological expectation of producing green and safe aquatic products, and then encourages them to carry out the safety factor input behavior. Order fishery not only can solve the production constraints faced by small-scale aquaculturists and effectively reduce the degree of aquaculture risk [42], but also can provide specific provisions on the production behavior and product quality of trading products in advance in the form of contracts, which will guide aquaculturists to carry out green production behavior and aquatic product quality control behavior. Generally speaking, participating in order fishery can encourage aquaculturists to pay more attention to the safety of factors input, then help them to do their best to produce green aquatic products, so that aquaculturists' awareness of green and safe production can be consciously incorporated into the aquaculture process of aquatic products.

\subsection{Intermediary Effect Analysis of Product Quality Certification}

The empirical results indicate that product quality certification has partial intermediary effects in the relationship between the fishery cooperatives' support and the safety factor input behavior of aquaculturists, and the intermediary effects account for $33.7 \%$ of the total effects, which indicates that partial effects of fishery cooperative support on the safety factor input behavior come from product quality certification. The possible explanation is that product quality certification is an important starting point for improving the quality level and market competitiveness of aquatic products. Since the important participants in product quality certification are cooperative organizations, they have strict production standards for aquaculturists who join product quality certification [43]. The support of fishery cooperatives can help aquaculturists reduce the complex procedures and improve their awareness of aquatic product quality certification and can also guide them to carry out safe production in strict accordance with the national product certification requirements of "three products and one standard". Generally speaking, the strictness and standardization of product quality certification can effectively improve the safety production awareness of aquaculturists [44] and can organize the knowledge popularization and standardized information service support of product quality certification to drive the green production of aquaculturists, helping them to more consciously form the self-disciplined behavior of safe green production. 


\subsection{Prospects for Research}

This paper mainly discusses the mechanism and influence of organizational support on safety factor input behavior of aquaculturists. In fact, the quality control process of aquatic products includes the whole process from pond to table, and there are quality and safety problems in each link. Future research should expand the research content as much as possible, incorporate organizational support into the analysis framework of aquatic product industry chain, and study the main behavior of aquatic product quality control in the key links of the industrial chain. At the same time, limited by time and ability, this paper only conducted a questionnaire survey in Rongcheng, Shandong, and Xiangshan, Zhejiang, and collected 586 fishers' questionnaires as data. As there are still great differences in the natural and cultural environment and in the level of industrial development, the data analyzed here may not fully reflect the overall situation of aquatic product production in other regions of China. Therefore, a follow-up study will expand the sample size, improve the sample representativeness, compare and analyze the characteristics of organizational support and aquatic product quality control in different regions, and draw a more general conclusion.

\section{Conclusions}

This paper used 586 survey data of aquaculturists in Shandong and Zhejiang provinces of China, and build two intermediary effect models by incorporating fishery cooperative support, order fisheries participation, product quality certification, and safety factor input behavior into the same theoretical analysis framework in order to verify the direct influence of fishery cooperative support on safety factor input behavior of aquaculturists, as well as to assess the intermediary effect of order fisheries participation and product quality certification in the relationship between fishery cooperative support and safety factor input behavior of aquaculturists. The research concludes that fishery cooperative support has a significant positive influence on safety factor input behavior. Participation in order fisheries and product quality certification have a partial intermediary effect in the relationship between fishery cooperative support and safety factor input behavior of aquaculturists; their intermediary effect accounts for $10.3 \%$ and $33.7 \%$ of the total effect. Combined with the research conclusions, China fishery cooperatives should implement a unified procurement system of fishery chemicals and should supervise farmers' safe production in the production process. Fishery cooperation organizations should pay attention to the pertinence of technical training in key links and should improve the technical training content of fishery cooperatives to enhance the safety production awareness of aquaculturists. The conclusions can provide reference and suggestions for China's fisheries as they better carry out green aquaculture.

Author Contributions: P.C. managed the model and data collection. P.C. performed sample analysis and data analysis interpretation. Q.H. prepared the outline of the manuscript structure, and P.C. wrote the initial version of the manuscript. All authors have read and agreed to the published version of the manuscript.

Funding: This research was funded by Major Projects of Social Planning in Zhejiang Province (No. 19XXJC02ZD), the general program of Chinese National Natural Science Foundation (No. 71874092), and key projects of the National Social Science Foundation (No. 19AZD004).

Institutional Review Board Statement: Not applicable.

Informed Consent Statement: Not applicable.

Data Availability Statement: The data of this paper mainly came from the questionnaires. The sample objects were aquaculturists in Rongcheng City, Shandong Province, and Xiangshan City, Zhejiang Province of China.

Conflicts of Interest: The authors declare no conflict of interest. 


\section{References}

1. Lu, K.; Gao, J.J.; Hao, P. Evaluation of my country's mariculture resources development and analysis of supporting policies. Issues Agric. Econ. 2016, 37, 95-103.

2. Le, J.H.; Dai, Y.; Liu, W.C. An Empirical Analysis of the Impact of Fishery Industry Structure on Economic Growth-Taking 9 Coastal Provinces as Examples. China Fish. Econ. 2019, 37, 13-20.

3. Chen, Y.S.; Yang, X.C.; Zhou, H.L. An Empirical Analysis of the Factors Influencing Consumers' Traceable Aquatic Products Purchase Behavior. J. Ocean. Univ. China (Soc. Sci. Ed.) 2012, 6, 49-54.

4. Zhang, M.; Huo, Z.H.; Song, M.S. Analysis of quality and safety control behaviors and influencing factors of marine farmers in Zhejiang Province. Agric. Mod. Res. 2016, 37, 318-324.

5. Mu, X.Y.; Huang, Y.; Luo, J.B.; Li, Y.R. Increased production and control of pollution, green development of aquaculture has achieved initial results-Interpretation of the second national survey of pollution sources on aquaculture emissions. Chin. Fish. Sci. 2021, 28, 389-390.

6. Tang, Q.S.; Ding, X.M.; Liu, S.L.; Wang, Q.Y.; Nie, P.; He, J.G.; Mcconson; Xu, H.; Lin, H.; Jin, X.S.; et al. China aquaculture industry green and sustainable development safeguard measures and policy recommendations. Chin. Fish. Econ. 2014, 3, 5-11.

7. Wang, Y.; Liang, J.P.; Yang, J.; Ma, X.X.; Li, X.Q.; Wu, J.; Yang, G.H.; Ren, G.X.; Feng, Y.Z. Analysis of the environmental behavior of farmers for non-point source pollution control and management: An integration of the theory of planned behavior and the protection motivation theory. J. Environ. Manag. 2019, 237, 15-23. [CrossRef]

8. Li, X.F.; Jiang, Q.J. Evaluation and analysis of green development of aquaculture in the Yangtze River Economic Zone. Chin. Fish. Econ. 2021, 39, 81-89.

9. Sterling, B.; Gooch, M.; Dent, B.; Marenick, N.; Miller, A.; Sylvia, G. Assessing the Value and Role of Seafood Trace ability from an Entire Value-Chain Perspective. Compr. Rev. Food Sci. Food Saf. 2015, 14, 205-268. [CrossRef]

10. Zeweld, W.; Huylenbroeck, G.V.; Tesfay, G.; Speelman, S. Smallholder farmers' behavioural intentions towards sustainable agricultural practices. J. Environ. Manag. 2017, 187, 71-81. [CrossRef]

11. Ping, Y.; Liu, D.D. 70 Years of Organizational Exploration of China's Fishery Production and Management. China Rural Econ. 2019, 11, 15-30.

12. Martinez, M.G.; Broffman, F. The role of trace-ability in restoring consumer trust in food chains. Vol. Wood Head Publ. Ser. Food Sci. Technol. Nutr. 2011, 17, 294-302.

13. Hu, Q.G.; Zhu, A.X. The impact of industrial chain coordination on the operation of aquatic product traceability system: Based on a survey of 209 aquatic products companies in China. China Rural Econ. 2017, 12, 49-64.

14. Zhao, L.; Sun, H.W.; Jiang, H.B. Research on the development of new fishery management entities based on the perspective of industrial integration. Guangdong Agric. Sci. 2019, 46, 162-172.

15. Liu, H.N.; Xiang, L. An Empirical Analysis of the Factors Influencing the Ecological Behavior of River Crab Farmers-Based on the Survey of Farmers in Jiangsu Province. Chin. Fish. Econ. 2019, 37, 68-75.

16. Lu, D.; Xi, Y.G.; Xia, X.J. Discussion on the Quality and Safety of Chinese Aquatic Products and Organic Aquaculture. China Popul. Resour. Environ. 2005, 15, 85-88.

17. Han, G.; Song, G.L.; Chen, X.Z.; Mu, Y.C.; Feng, D.G. Analysis on the construction of aquatic product quality and safety traceability system. China Fish. 2018, 12, 47-49.

18. Xue, X.L.; Chen, Y.S.; Phetphanthong, S.; Li, Z.D. Game Analysis of Aquatic Product Geographical Indications Supervision Based on Experimental Economics. Macro Qual. Res. 2018, 7, 41-50.

19. Olaf, O.J. Environmental problems and regulation in the aquaculture industry. Insights from Norway. Mar. Policy 2018, 98, 158-163.

20. Eisenberger, R.; Fasolo, P.; Davislamastro, V. Perceived Organizational Support and Employee Diligence, Commitment and Innovations. J. Appl. Psychol. 1990, 75, 51-59. [CrossRef]

21. Muse, L.A.; Stamper, C.L. Perceived organizational support and Its consequences: Evidence for a mediated association with work performances. J. Manag. Issues 2007, 19, 517-535.

22. Ling, W.Q.; Yang, H.J.; Fang, L.L. Organizational support of enterprise employees. J. Psychol. 2006, 2, $281-287$.

23. Bao, G.M.; Liu, X. Research on multi-dimensional conceptual model supported by perception organization. Sci. Res. Manag. 2011, 32, 160-168.

24. Tregurtha, N.L.; Vink, N. Trust and Supply Chain Relationship: A South African Case Study. Annu. Conf. Pap. Int. Soc. New Inst. Econ. 2002, 9, 27-29. [CrossRef]

25. Li, M. Market failure and the localization model of aquaculture insurance-Based on a comparative study of aquaculture pilots in five provinces and cities. China Fish. Econ. 2017, 35, 66-71.

26. Wang, F.G.; Lin, J.F. The impact of leading agricultural enterprises on the quality and safety behavior of aquaculture farmers. $J$. Huazhong Agric. Univ. (Soc. Sci. Ed.) 2015, 6, 11-18.

27. Steg, L.; Vlek, C. Encouraging pro-environmental behaviour: An integrative review and research agenda. J. Environ. Psychol. 2009, 29, 309-317. [CrossRef]

28. He, J. A review of Chinese fish trade involving the development and limitations of food safety strategy. Ocean Coast. Manag. 2015, 116, 150-161. [CrossRef] 
29. Dereje, T.R.; Nega, A.A. Determinants of Climate Change Mitigation and Adaptation strategies: An Application of Protection Motivation Theory. Rural Sustain. Res. 2019, 42, 9-25.

30. Yu, J.K.; Li, W.W. Analysis of Government Incentive Mechanism for Pollution Control in the Development of Marine ResourcesTaking Mariculture as an Example. J. Zhejiang Ocean Univ. (Humanit. Ed.) 2010, 27, 8-14.

31. Cao, J.H. A case study on the green development model and ecological support policy of aquaculture industry. Rural Econ. 2018, $5,34-39$.

32. Campos, E.V.; Proença, P.L.; Oliveira, J.L.; Bakshi, M.; Abhilash, P.C.; Fraceto, L.F. Use of botanical insecticides for sustainable agriculture: Future perspectives. Ecol. Indic. 2019, 105, 483-495. [CrossRef]

33. Zheng, J.M.; Zhang, X.G.; Huang, T. An Empirical Analysis of the Impact of Government Regulations on Aquaculture Quality and Safety on the Economic Benefits of Farmers-Based on the Case of Shanghai. Shanghai Econ. Res. 2011, 3, 92-99.

34. Dickson, M.; Nasr-Allah, A.; Kenawy, D.; Kruijssen, F. Increasing fish farm profitability through aquaculture best management practice training in Egypt. Aquaculture 2016, 465, 172-178. [CrossRef]

35. Wu, Y.; Xi, X.C.; Tang, X.; Luo, D.M.; Gu, B.J.; Lam, S.K.; Vitousek, P.M.; Chen, D.L. Policy distortions, farm size, and the overuse of agricultural chemicals in China. Proc. Natl. Acad. Sci. USA 2018, 27, 7010-7015. [CrossRef] [PubMed]

36. Yang, X.L.; Zheng, Z.L. The current situation, existing problems and countermeasures of the use of fishery drugs in my country. J. Shanghai Fish. Univ. 2007, 4, 374-380.

37. Feng, D.Y. Discussion on the technical measures of aquaculture drug reduction and efficiency enhancement. China Fish. 2017, 8, 49-52.

38. Lee, G.; Suzuki, A.; Nam, V.H. Effect of network-based targeting on the diffusion of good aquaculture practices among shrimp producers in Vietnam. World Dev. 2019, 124, 104641. [CrossRef]

39. Tran, N.H.; Gin, K.Y.H. Occurrence and removal of pharmaceuticals, hormones, personal care products, and endocrine disrupters in a full-scale water recl amation plant. Sci. Total Environ. 2017, 599-600, 1503-1516. [CrossRef]

40. Jia, B.; St-Hilaire, S.; Singh, K.; Gardner, I.A. Bio-security knowledge, attitudes and practices of farmers culturing yellow catfish (Pelteobagrus fulvidraco) in Guangdong and Zhejiang provinces, China. Aquaculture 2017, 471, 146-156. [CrossRef]

41. Joffre, O.M.; Vries, J.D.; Klerkx, L.; Poortvliet, P.M. Why are cluster farmers adopting more aquaculture technologies and practices? The role of trust and interaction within shrimp farmers' networks in the Mekong Delta, Vietnam. Aquaculture 2020, $523,735181$. [CrossRef]

42. Wang, X.J.; Hu, Q.G. Analysis of the coordination degree between mariculture and marine ecological environment in China. China Rural Econ. 2013, 11, 86-96.

43. Gong, Y.; Baylis, K.; Kozak, R.; Bull, G. Farmers'risk preferences and pesticide use decisions: Evidence from field experiments in China. Agric. Econ. 2016, 47, 411-421. [CrossRef]

44. Zhang, Q.; Lu, Q.J.; Wei, Y.Z. Analysis of the willingness of marine farmers to develop ecological aquaculture models and influencing factors. Fujian Forum (Humanit. Soc. Sci. Ed.) 2020, 3, 105-114. 